\title{
The Visual and Quantitative Study of the Microoccurrence of Irreducible Water at the Pore and Throat System in a Low-Permeability Sandstone Reservoir by Using Microcomputerized Tomography
}

\author{
Xiaoyu Gu, ${ }^{1,2}$ Chunsheng Pu $\mathbb{D}^{1,2}$ Hai Huang, ${ }^{3}$ Nasir Khan, ${ }^{1,2}$ Jing Liu, ${ }^{1,2}$ Yanlong He, ${ }^{3}$ \\ Cheng Jing, ${ }^{3}$ Feifei Huang, ${ }^{1,2}$ and Aojiang $\mathbf{Q i}^{3}$ \\ ${ }^{1}$ School of Petroleum Engineering, China University of Petroleum (East China), Qingdao, Shandong 266555, China \\ ${ }^{2}$ China National Key Laboratory for Heavy Oil, Qingdao, Shandong 266555, China \\ ${ }^{3}$ School of Petroleum Engineering, Xi'an Shiyou University, Xi'an, Shanxi 710065, China \\ Correspondence should be addressed to Chunsheng Pu; chshpu_tx@126.com
}

Received 29 March 2018; Accepted 14 June 2018; Published 6 August 2018

Academic Editor: Xiangzhao Kong

Copyright $\odot 2018$ Xiaoyu Gu et al. This is an open access article distributed under the Creative Commons Attribution License, which permits unrestricted use, distribution, and reproduction in any medium, provided the original work is properly cited.

\begin{abstract}
The microflow equipment monitored with micro X-ray computerized tomography (CT) is employed to investigate the microoccurrence of the irreducible water in a low-permeability sandstone core. By means of image segmentation and the threedimensional (3D) image reconstruction technique, the visual microdistribution characteristics of irreducible water in twodimensional (2D) slices and the 3D pore-throat system are quantitatively evaluated. Some interesting findings are list as below. Firstly, due to the variant micro geometric structures of the pore-throat systems, specific core slices showed significantly different irreducible water saturation even though these slices had same areal porosity. Secondly, due to the influence of capillary trapping and the existence of oil-wetting clay (main chlorite), the irreducible water saturation in the throat system (64\%) is much larger than that in the pore system (36\%). Furthermore, the wetting phase (irreducible water) did not spread all over the surface of the pore-throat network which caused a much more complicated oil-water two-phase interface. Thirdly, in micro scale, the main irreducible water occurrence mode in the pore system is much different from that in the throat system. In the pore system, the irreducible water principally existed in the corner of the pores which are linked through a water film. While in the throat system, the irreducible water occurrence is dominated by the water film. However, $25.5 \%$ of the throats are blocked by the irreducible water which cut off the crude oil drainage channels.
\end{abstract}

\section{Introduction}

With the increasing worldwide demand for crude oil, lowpermeability reservoirs are considered to overcome the energy deficit in developing countries $[1,2]$. Theory and practice have proved that water flooding is the most economical technology to replenish formation energy and enhance oil recovery (EOR) in low-permeability reservoirs [3]. During the water flooding, many geological factors determine the efficiency of water drives, such as rock permeability, porethroat structure, irreducible water saturation, and crude oil viscosity [4-6]. Among these factors, the microdistribution of irreducible water confined in the pore-throat system is one of the critical factors affecting the ultimate recovery [7]. Because of pore geometry structure, the microdistribution of irreducible water in porous media is very complicated. [8]. According to the results of Kewen Li and Roland N. Horne, the irreducible water saturation has a considerable effect on the spontaneous imbibition recovery. Higher irreducible water saturation is always correlated to the lower recovery tendency in low permeable rock [9]. This phenomenon is also verified by Wang et al. [10]. Therefore, how to obtain the quantitative visualized information about the irreducible water microdistribution is necessary to 
investigate the mechanisms of irreducible water on microflow behaviors in low permeable porous media. For this purpose, specific techniques are currently employed which will be discussed in the below paragraphs.

The two-dimensional (2D) etching glass model and core displacement monitored by nuclear magnetic resonance (NMR) are the main qualitative and quantitative approaches, respectively, to look into the fluid occurrence and its distribution in porous media [11-14]. The principal advantage of the former experimental method is to visualize the water displacement. Specifically, the wettability difference between the natural porous surface and modeled interface poorly reflects the real microdisplacement in natural core samples. Also, the $2 \mathrm{D}$ etching glass model cannot be perfectly related to the natural 3D core sample. The above discrepancies have constrained the application of the qualitative approach. As far as core displacement based on NMR is concerned, it is a currently reliable method to determine the distribution of fluids in porous media [15-19]. However, 3D visualization of the natural core sample could not be perfectly developed. As a result, it is essential to look for such a novel experimental method which can perfectly encompass the quantitative microdistribution of irreducible water in $3 \mathrm{D}$ porous media along with the acquisition of high-resolution visualizations.

The recent improvement in CT scanning resolution from micron to nanoscale makes it possible for the researchers to investigate pore scale and contained fluid in the low permeable core samples [20-23]. Due to high-precision 3D visualization and quantitative characterization, this technology overcomes the shortcomings of conventional experiment methods [24]. Nevertheless, owing to a limitation in the microflow device, CT scanning technology was frequently applied to analyze the micro pore-throat structure in dry core samples [25-27]. In contrast, this technology was seldom used in research of fluid microdistribution characteristics in low permeable sandstone. The considerable research was conducted to analyze water or gas flooding to investigate the evolution law of residual oil in high-permeability core samples using the CT scanning technique [28-30]. However, to the best of our knowledge, scarce literature is available that has perfectly visualized and quantified the microoccurrence of irreducible water in the pore and throat system [31]. Besides, owing to the huge difference between pore and throat geometries, particularly in low-permeability porous media, the microoccurrence of irreducible water is very complicated. Consequently, it led to lack of in-depth understanding of the microinfluence mechanisms of irreducible water on oil-water two-phase flow behaviors.

The key aim of this study is to investigate the irreducible water microoccurrence which was confined in the pore and throat system in low permeable sandstone, taking the Chang2 low-permeability reservoir sandstone of Ordos Basin in northwest China as a case study. Afterwards, the microflow equipment monitored by micro X-ray computerized tomography (CT) is employed to investigate the microoccurrence of the irreducible water in the pore-throat system. Subsequently, the visible information of the pore-throat structure and irreducible water in the pore-throat network is acquired with 1.5 microns per pixel. Besides, the microdistribution characteristics of irreducible water in two-dimensional (2D) core slices and 3D pore-throat network are also quantitatively evaluated using the image segmentation and threedimensional (3D) image reconstruction technique. As a consequence, our work would provide reliable experimental evidence for recognizing the micro hydrodynamic mechanisms which play a pivotal role in enhancing water-flooding displacement effectiveness.

\section{Experiments}

2.1. Rock Sample and Fluids. According to the China National Petroleum Corporation's reservoir quality grading standards (SY/T6285-2011), the Triassic Yanchang Chang2 formation in Ordos Basin is declared as a typical lowporosity and low-permeability reservoir [32]. The oil and core samples were obtained from the Chang2 reservoir in Ordos Basin, northwest China. The parameters of the fluid and rock samples used in this experiment are as follows. Simulated oil had $6.4 \mathrm{mPa} \cdot \mathrm{s}$ dynamic viscosity at $25^{\circ} \mathrm{C}$ temperature. Simulated formation brine was prepared by dissolving potassium iodide (KI). The salinity of formation water is $70,000-90,000 \mathrm{mg} / \mathrm{L}$ in the given formation. Therefore, $8 \mathrm{wt}$. $\%(\mathrm{KI})$ brine solution was injected for the reason to exactly simulate the formation water. In this way, the density difference between oil and brine (KI) was enhanced in comparison to distilled water. Furthermore, it could help to differentiate between the oil and water phase in the CT image. Consequently, contained fluids, such as water and oil, could easily be distinguished by image segmentation step. The sandstone core sample that was used in this study has a $5 \mathrm{~mm}$ diameter and $10 \mathrm{~mm}$ length as shown in Figure 1. The gas permeability and porosity are $4.25 \times 10^{-3} \mu \mathrm{m}^{2}$ and $15.3 \%$, respectively.

2.2. Experimental Apparatus. A micron CT scanning equipment and microdisplacement device are shown in Figure 2. The experimental parameters of the microdisplacement system and CT scanning are all controlled by a computer. Other instruments used in this research goal are a HAAKE RS600 Rheometer (Thermo Scientific, Germany), a DV-III Brookfield viscometer (Brookfield Company, America), and a 510 model micrometer CT scanner (Zeiss, Germany).

2.3. Experimental Procedure. Before acquiring a highresolution image, the CT scanning equipment is configured with $50 \mathrm{KeV}$ operational voltage, $1.5 \mathrm{~s}$ exposure time span, and 1.5 microns per pixel scanning precision. Besides, the slice thickness is $1.5 \mu \mathrm{m}$ which contains $1024 \times 1024$ pixels. These parameters can meet the requirement of pore size recognition above the micron level. The exact experimental procedure is as follows:

(1) The system consisting of a CT scanner and flow cell system is assembled as shown in Figure 2. After that, a selected core sample is fixed in the core holder.

(2) Vacuum (0.1 MPa) the core sample under a confining pressure of $0.1 \mathrm{MPa}$ for 10 hours. Scan the core by CT to obtain the characteristics of pore-throat structures (pore volume as well) of the core. 


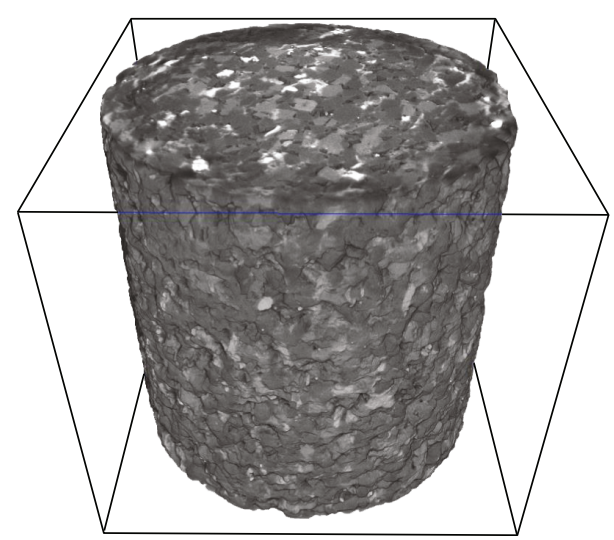

Figure 1: The CT scanning image of the core sample.

(3) Close the vacuum valve. Then, saturate the core with brine (5 PV) at a low speed of $0.002 \mathrm{~mL} / \mathrm{min}$. The confining pressure was held at least $0.5 \mathrm{MPa}$ higher than the injection pressure. Then the sample was kept for 72 hours.

(4) Saturate the core sample with oil (5 PV) by constant flowrate of $0.002 \mathrm{~mL} / \mathrm{min}$ at room temperature $\left(25^{\circ} \mathrm{C}\right)$. In this way, the oil was driven through the core to generate the irreducible water in the core. After keeping the core sample at room temperature $\left(25^{\circ} \mathrm{C}\right)$ for 72 hours, CT scanning is conducted to obtain the microdistribution of the irreducible water contained in the pore-throat network.

\section{Image Processing and Analysis}

3.1. Image Segmentation. Image segmentation is the fundamental part for the distinction of rock particles, the oil phase, and the water phase in the porous media. Median filtration method based on a nonlinear signal processing was used to minimize the noise in the scanning images. More specifically, the filtering mechanism is detailed in Andrew's dissertation [33]. The images before and after median filtration are shown in Figure 3.

By following the abovementioned procedure, the core sample would contain three kinds of substances, such as rock particles, water, and oil. It is visualized on the basis of different X-ray propagations in the abovementioned phases which led to the variant scanning gray peak of each phase. The corresponding peak intensity for rock particles, water, and oil is $18,700,10,400$, and 11,700 , respectively. Therefore, it could be distinguished from image segmentation. As a result, the acquired image segmentation outcomes are shown in Figure 4.

3.2. Image 3D Reconstruction. Two-dimensional image segmentation of core sample slices was obtained. Then, the distribution of pore-throat, oil, and water in all 2D slice images was acquired. In the next step, the ORS 3D software was used to add all the $2 \mathrm{D}$ images to become a $3 \mathrm{D}$ dataset. The $3 \mathrm{D}$ reconstruction principle is based on the marching cube algorithm [34]. After that, the visualized 3D distribution of the pore-throat, oil, and water in the core sample was obtained as shown in Figure 5 and Table 1.

\subsection{Quantitative Analysis Method}

3.3.1. Calculation of Surface Area and Volume of the Data Cube. Pixels are the basic unit of the building dataset, and these pixel dots of irreducible water and rock particles were obtained after image segmentation. In the next step, the characteristic parameters, for instance, the surface area and the volume of irreducible water and the pore-throat in the core samples, can be calculated using the following equations.

$$
V_{i}=N_{v} \times V_{P},
$$

where $V_{i}$ is the volume of pixel dots $\left(\mu \mathrm{m}^{3}\right), N_{v}$ is the total number of the pixel dots of the same phase (dimensionless), and $V_{P}$ is the volume of a single pixel dot which is $3.375 \mu \mathrm{m}^{3}$ in this experiment.

$$
S_{i}=N_{s} \times S_{p},
$$

where $S_{i}$ is the surface area of a given phase $\left(\mu \mathrm{m}^{2}\right), N_{s}$ is the number of pixel dots of a given phase (dimensionless), and $S_{p}$ is the surface area of a single pixel dot which is $9.0 \mu \mathrm{m}^{2}$ in this experiment.

3.3.2. Microoccurrence of Irreducible Water in the PoreThroat Network. Due to the micro-occurrence of irreducible water in pore-throat network is very complicated. Hence, different parameters, such as the shape factor and the irreducible water saturation in a given single pore-throat, were used to categorize the complex heterogeneous structures of the given irreducible water block.

$$
G_{i}=\frac{6 \sqrt{\pi} V_{w}}{S_{w}^{1.5}},
$$

where $G_{i}$ is the shape factor of the irreducible water block (dimensionless), $V_{w}$ is the volume $\left(\mu \mathrm{m}^{3}\right)$, and $S_{w}$ is the surface area of the irreducible water block $\left(\mu \mathrm{m}^{2}\right)$. The shape factor represents the degree of sphericity of an object. In other terms, the lower the $G_{i}$ value, the more would be the shape irregularity of the given irreducible water blocks and, subsequently, the higher would be the surface roughness. In contrast, the greater the $G_{i}$ value, the more smooth the surface would be and the more likely the shape would be spherical.

Saturation of irreducible water $\left(S_{S_{\mathrm{wi}}}^{\prime}\right)$ shows the amount of irreducible water in a given pore or throat. This parameter can be obtained using (4). In general, the higher the irreducible water saturation $\left(S_{\mathrm{Swi}}{ }^{\prime}\right)$, the lower would be the flowability in a given channel.

$$
S_{\mathrm{Swi}}^{\prime}=\frac{V_{w}}{V_{\mathrm{p}-\mathrm{t}}} \times 100 \%,
$$

where $S_{S_{w i}}{ }^{\prime}$ is the saturation of irreducible water in either the pore or the throat (\%), $V_{w}$ is the irreducible water volume confined in a given pore or throat $\left(\mu \mathrm{m}^{3}\right)$, and $V_{\mathrm{p}-\mathrm{t}}$ is the pore or throat volume $\left(\mu \mathrm{m}^{3}\right)$. 


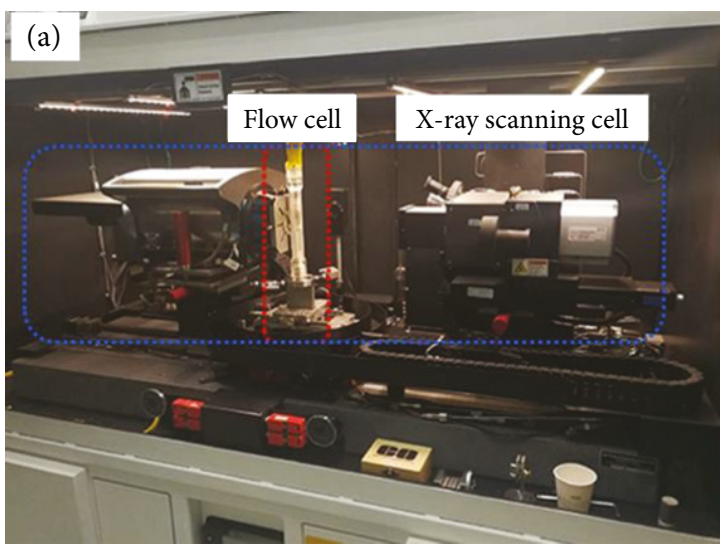

(a)

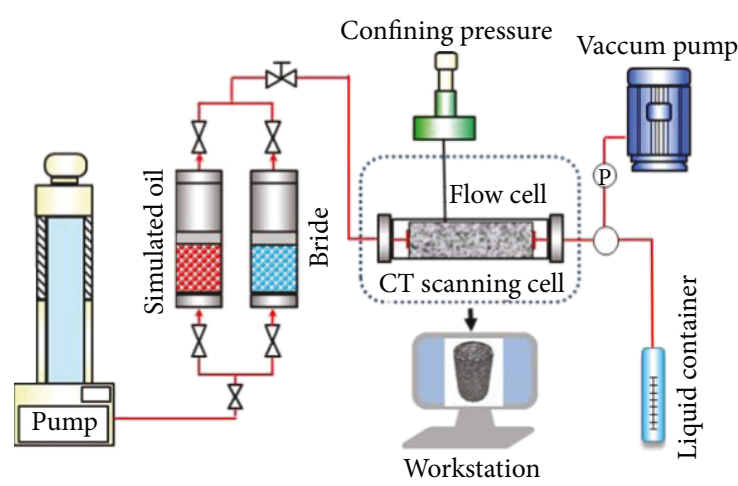

(b)

FIGURE 2: (a) The image of a microflow equipment monitored by micro X-ray computerized tomography. (b) The schematic illustration of the microflow equipment. Note: the pumps and valve arrangement is used to control fluid flow to the flow cell within the CT enclosure.

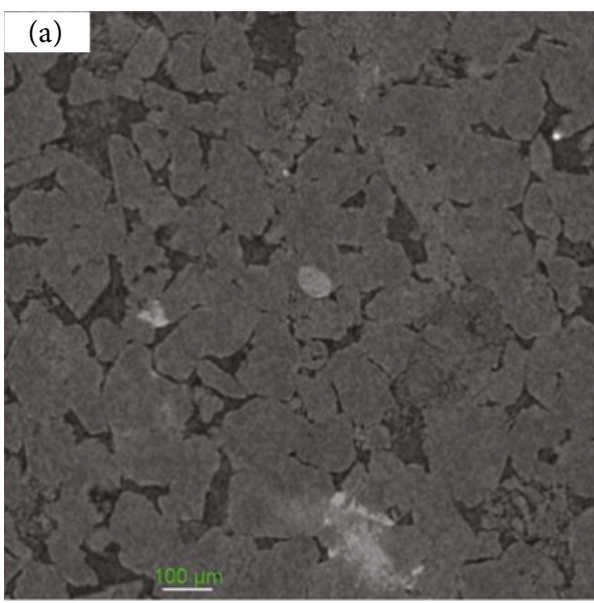

(a)

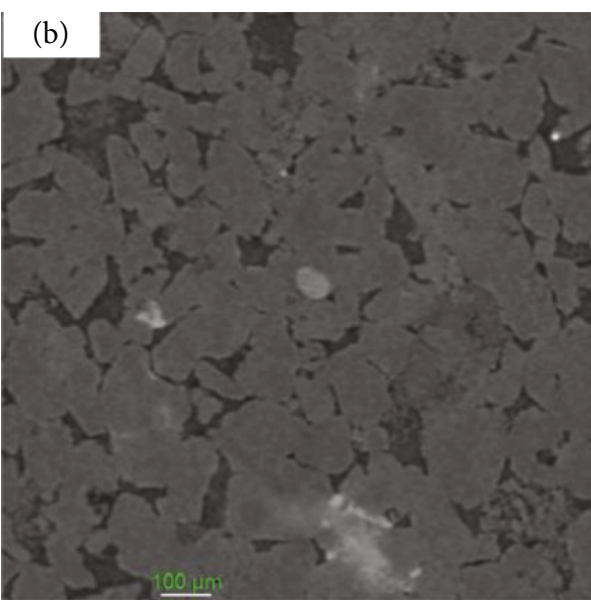

(b)

Figure 3: Images filtration (a) before and (b) after.

\section{Results and Discussion}

This section of the current study mainly emphasizes on three aspects: irreducible water distribution characteristics in 500 2D slices, 3D pore-throat network, and microoccurrence modes in the pore and throat system.

4.1. Distribution Characteristics of Irreducible Water in $2 D$ Slices. In this section, irreducible water distribution and its exact content in 500 2D core slices are evaluated by areal porosity and irreducible water that is contained in the porethroat space (after image segmentation). Meanwhile, the irreducible water saturation of each slice is mathematically calculated using (5), where the areal porosity and irreducible water porosity can be figured out in Figure 6(a).

$$
S_{\text {swi }}=\frac{\phi_{p}}{\phi_{\text {swi }}} \times 100 \%,
$$

where $S_{\text {swi }}$ is the irreducible water saturation for a given $2 \mathrm{D}$ scanning slice $(\%), \phi_{p}$ is the areal porosity of a $2 \mathrm{D}$ slice (\%), and $\phi_{\text {swi }}$ is the areal porosity of irreducible water in a given $2 \mathrm{D}$ slice (\%).

Irreducible water saturation distribution of all 2D slices is explicitly represented in Figure 6(b) that illustrates the irreducible water saturation alteration in the flow direction. For the evaluated irreducible water saturation in all 2D core slices, the maximum irreducible water saturation is measured to be $50.69 \%$ (slice number: 226), while the minimum irreducible water saturation remains at $26.59 \%$ (slice number: 343). At the same time, the average value of irreducible water saturation is $36.94 \%$. Additionally, three typical areas along with the alteration of the irreducible water saturation in the flow direction, including the peak, medium, and low regions are identified in Figure 6(b). The average saturation is up to $48.08 \%$ in the high-value zone in the continuous region (slice numbers: 213-232). In the peak-value area, average irreducible water saturation is $36.42 \%$ in the continuous part (slice numbers: 152-171). As far as the low-value part is concerned, average irreducible water saturation is $29.04 \%$ in the continuous part (slice numbers: 333-352). 


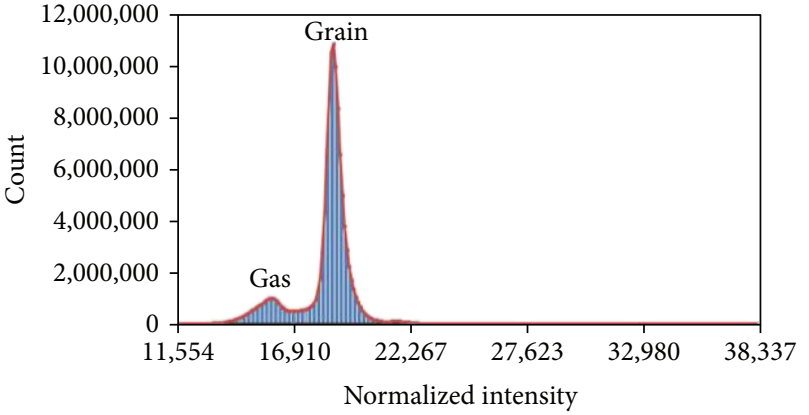

(a)

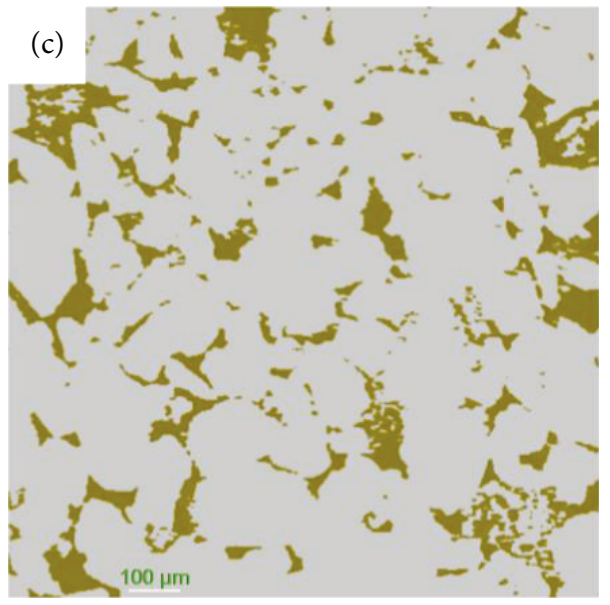

(c)

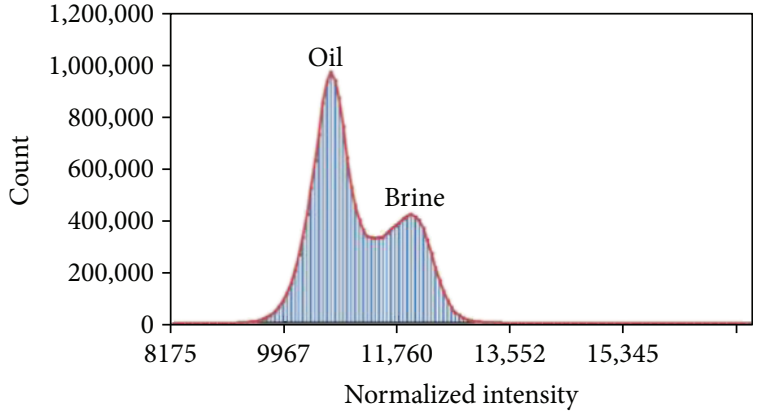

(b)

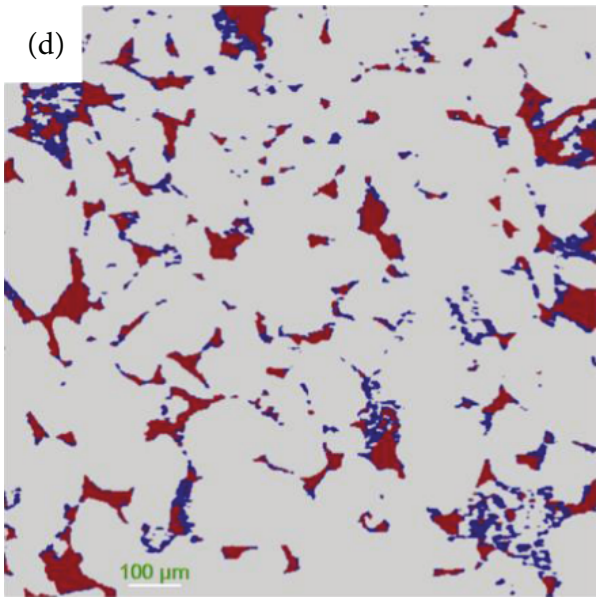

(d)

FIGURE 4: Images segmentation results: (a) intensity of gas and grain; (b) intensity of oil and brine; (c) pore-throat network and rock matrix; (d) oil and irreducible water. Note: yellow = pore-throat; gray = rock particles; blue = irreducible water; red = oil.

Figure 6(c) shows the frequency histogram of irreducible water saturation distribution of all slices in the core sample. It indicates that the law of irreducible water saturation (core slices) belongs to a normal distribution, where the peakvalue region of irreducible water saturation ranges from $35 \%$ to $40 \%$, while the irreducible water saturation value in either the high-value part (over 40\%) or the low-value region (below 30\%) shares lesser proportions with the corresponding frequency value of $6.8 \%$ and $5.6 \%$.

A reasonable relationship between irreducible water saturation and areal porosity can be shown in Figure 6(d). It indicates that (i) an inverse relation is observed between irreducible water saturation and porosity. Moreover, the line became steeper at higher areal porosity. (ii) A significant difference in irreducible water saturation existed among the slices even at the same areal porosity.

To investigate the reason for the phenomenon of the same (similar) areal porosity with a significant difference in $2 \mathrm{D}$ slice irreducible water saturation, three typical slices were selected as shown in Figure 7.

Despite the same porosity of the three slices (16.1\% 16.4\%), the corresponding irreducible water saturation is measured to be $29.57 \%, 36.37 \%$, and $50.69 \%$ as shown in Figure 7. Due to the capillary force, rock surface wettability, and pore geometry, the displacing oil mainly existed in the large-size pore and connected pore-throat. The variant irreducible water saturation in the case of identical porosity of three slices is due to the difference in pore-throat geometry. In the case of the higher pore radius, fewer pore corners, and lesser narrow throats, lower irreducible water saturation would exist in 2D slices. The distribution characteristics of 2D-slice irreducible water saturation are shown in Figure 8. It can be inferred that the irreducible water is mainly trapped by capillary force. In addition, the in-depth analysis helps to classify irreducible water into three main types:

(i) Water trapped in pendular rings in complex angular pore geometry beside surface roughness (stationary fluid part).

(ii) Water trapped in dead ends of the pore-network (pore corner).

(iii) Water film adherence in wider throats, while narrow throats filled with irreducible water.

4.2. Distribution Characteristics of Irreducible Water in the $3 D$ Pore-Throat Network. The pore-throat network governs the liquid flow in low-permeability porous media. However, distinct distribution characteristics of irreducible water exist in the pore-throat network. The pore and throat system recognition was based on the $3 \mathrm{D}$ reconstruction technology. The maximal inscribed sphere algorithm was used to identify the 


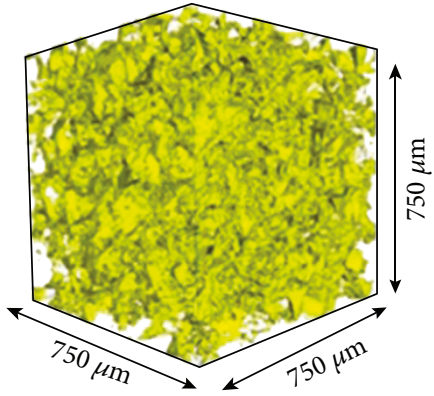

(a)

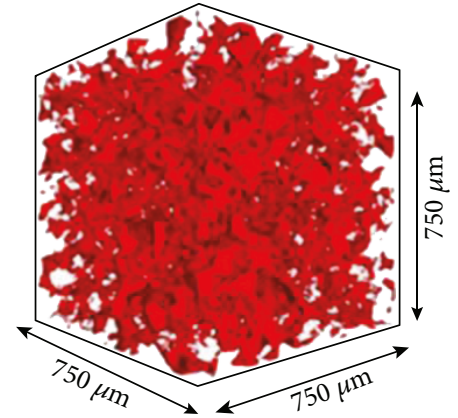

(b)

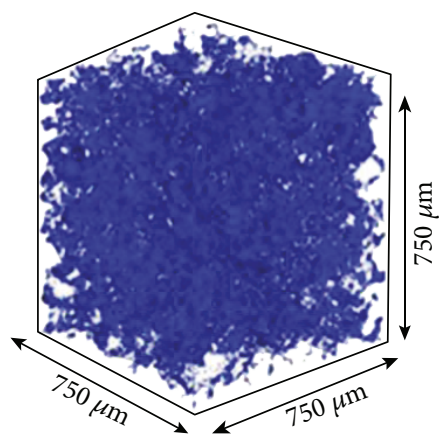

(c)

FIGURE 5: 3D reconstruction results. Note: (a) distribution of the pore-throat system in the core sample; (b) distribution of irreducible water; (c) distribution of simulated oil.

TABLE 1: Segmentation result of the core sample containing irreducible water.

\begin{tabular}{lccc}
\hline $\begin{array}{l}\text { Pore and throat } \\
\left(\text { volume } / \mu \mathrm{m}^{3}\right)\end{array}$ & $\begin{array}{c}\text { Irreducible water } \\
\left(\text { volume } / \mu \mathrm{m}^{3}\right)\end{array}$ & $\begin{array}{c}\text { Oil } \\
\text { volume } \\
\left(\mu \mathrm{m}^{3}\right)\end{array}$ & $\begin{array}{c}\text { Irreducible water } \\
\text { saturation }(\%)\end{array}$ \\
\hline $5.80 \times 10^{7}$ & $2.14 \times 10^{7}$ & $3.67 \times 10^{7}$ & 36.94 \\
\hline
\end{tabular}

certain throat part in varying diameter channels. Along with the connected channel, the shortest distance portion was categorized as the throat. While the connected spherical-shaped body is recognized as the pore. The principle of pore and throat recognition is shown in Figure 9. The details of pore and throat classification methods and principles are reported in Denney and Yang et al. [35, 36]. The information of overall 3D distribution characteristics of irreducible water is extracted by identification of 3D coordinates of the irreducible water pixels existing in the pore and throat system as shown in Figure 10.

According to the $3 \mathrm{D}$ reconstruction results based on CT scanning, the volumes of the pore system and throat system are determined to be $5.63 \times 10^{7} \mu \mathrm{m}^{3}$ and $1.69 \times 10^{6} \mu \mathrm{m}^{3}$, respectively. Moreover, the radius distribution, in either case, followed a normal distribution (Figure 10), where the peakvalue regions of the pore and throat system are found in the $25-30 \mu \mathrm{m}$ and $2-2.5 \mu \mathrm{m}$ ranges, respectively (Figure 11 ). This fundamental information provides a better platform for less proportion of irreducible water saturation in the pore system than the throat system (Figure 12). The exact irreducible water saturation proportions are figured out to be (36\%) in the pore system which is far less than in the throat system (64\%) (Figure 13). This low percentage of irreducible water saturation in the pore system could be attributed to the difference in radius. It is a well-understood fact that permeability of a porous matrix is chiefly relying on the throat radius. However, irreducible water occupied the throat system either in the form of water film or being completely filled with it. Consequently, the effective throat radius would further be decreased in the flooding fluid. This obtained knowledge provided a rationalized answer to the high water-flooding pressure and low hydrocarbon recovery in a low-permeability reservoir. Characteristic parameters of irreducible water, including numbers and volume that exist in the pore and throat system with different sizes, are quantitatively studied in the upcoming part of the current section. In this connection, distribution of frequency number and irreducible water volume in different sizes of the pore and throat system is determined by following the same calculation method which is discussed in Section 3.3. As a consequence, the results are elucidated in Figures 14 and 15.

Figure 14 relates frequency number and volume number to irreducible water saturation in the throat system. It is shown that both characteristic parameters sharply decrease upon an increase in irreducible water saturation in the range of volume less than the average throat volume. Furthermore, this phenomenon can further be interpreted by throat radius determination. As it is widely accepted that the throat volume is proportional to the throat radius which subsequently provides a relatively larger flow area. Consequently, the 


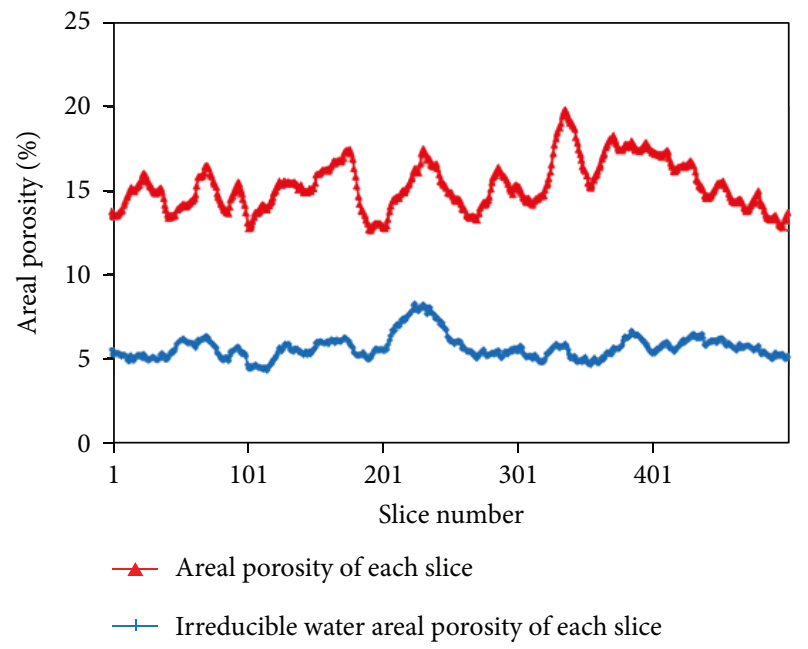

(a)

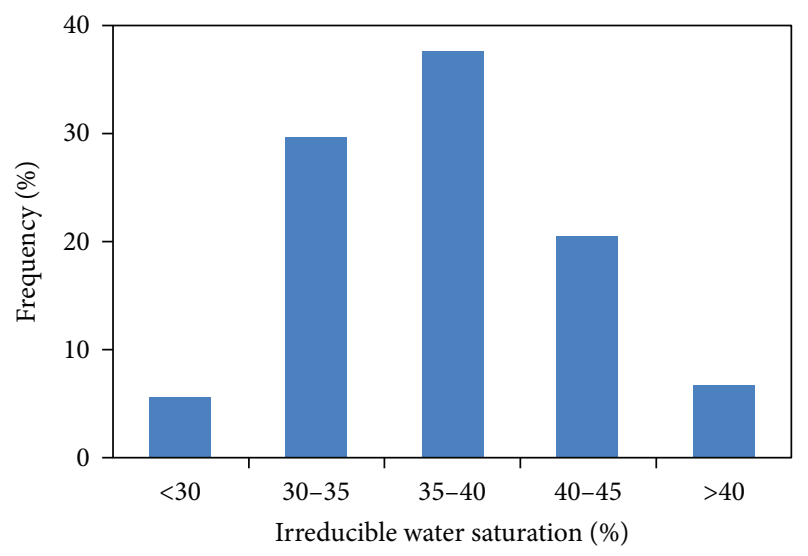

(c)

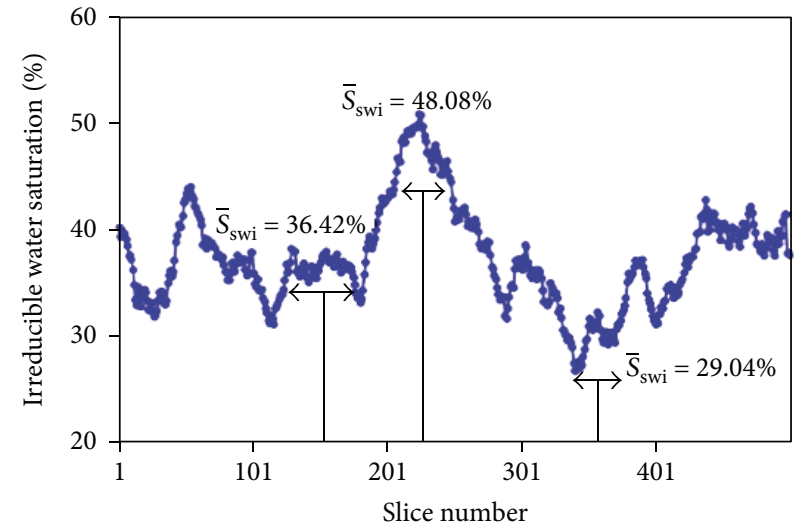

(b)

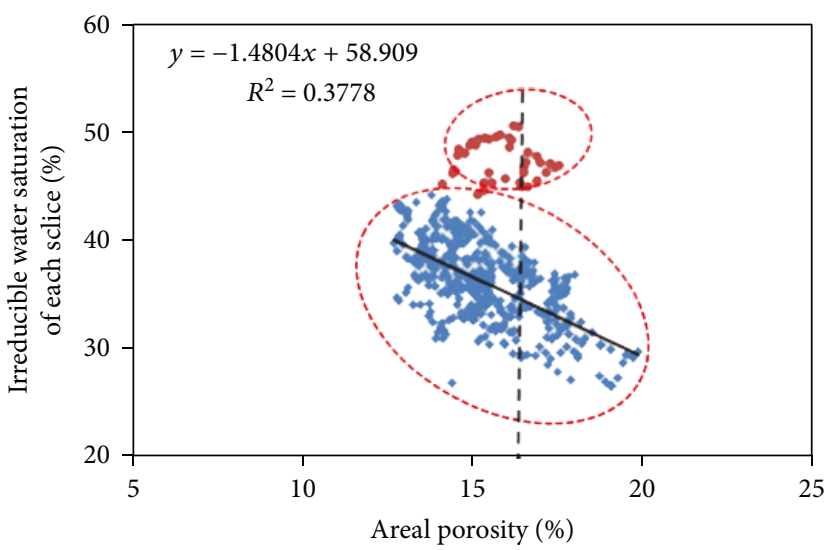

(d)

FIGURE 6: 2D distribution characteristics of irreducible water in core slices: (a) distribution of areal porosity and irreducible water porosity in $2 \mathrm{D}$ core slices; (b) distribution of irreducible water saturation of a $2 \mathrm{D}$ slice; (c) frequency histogram of irreducible water distribution in the core sample; (d) relationship between areal porosity and irreducible water saturation.

exerted capillary force in a comparatively larger flow area would decrease, and it further resulted in the reduction in the throat's capability to trap irreducible water during the process of oil displacement.

Figure 15 shows that the distribution frequency of the number of irreducible water in the pore system and throat system followed a similar trend, but the volume of irreducible water in the pore system and throat system varies slightly (Figures 14(a) and 15(a)). We can see that with the increase in the number of irreducible water blocks, the trend of the volume frequency distribution of irreducible water with different sizes first descended and then increased. This dramatic turning point (Figure 15(a)) in the trend happened when the volume of irreducible water was over $10^{5} \mu \mathrm{m}^{3}$. This obscure behaviour is explained as; since there are 13 irreducible water blocks in pore system which has volume over $10^{5} \mu \mathrm{m}^{3}$, these 13 irreducible water blocks were extracted. On this basis, the 13 pore spaces were retrieved that contained the corresponding 13 irreducible water blocks. In next step, $S_{\text {Swi }}^{\prime}$ was calculated. Consequently, results showed that $S_{\text {Swi }}{ }^{\prime}$ fell in the
$80-98 \%$ range. It can be inferred that this dramatic turning is due to poor sweeping of irreducible water during oil displacement.

4.3. Microoccurrence of Irreducible Water in the Pore and Throat System. The 3D structure of irreducible water distribution in pore space is complicated due to the combined effect of porous media heterogeneity and the oil-water displacement process. Meanwhile, by $3 \mathrm{D}$ visualization, the irreducible water microoccurrence in pore and throat systems is categorized into each mode (Figures 16 and 17), which are further explained below:

(a) Irreducible water in the pore system:

(i) Conglobation shape: this kind of pores has comparatively small room and has a complicated structure. Moreover, they are produced due to dissolution at different stages and are referred to secondary pores. Referring to irreducible 


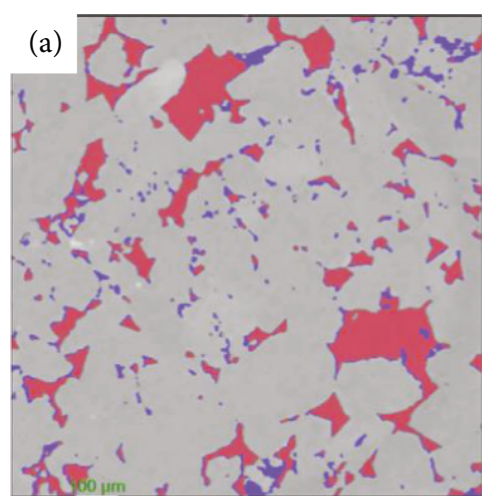

(a)

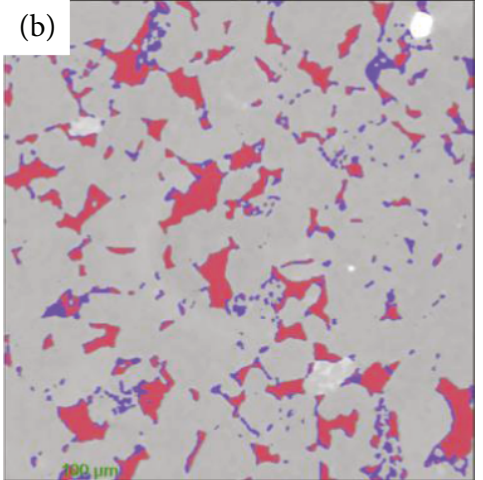

(b)

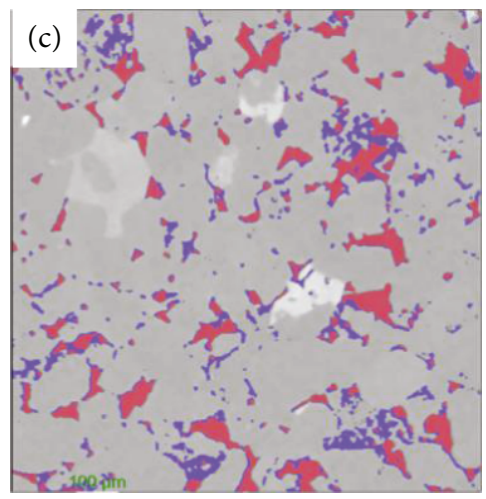

(c)

Figure 7: Distribution of irreducible water saturation of a given slice with the same areal porosity (void space): (a) $S_{\text {swi }}=29.57 \%$ (slice number: 362); (b) $S_{\mathrm{swi}}=36.37 \%$ (slice number: 425); (c) $S_{\mathrm{swi}}=50.69 \%$ (slice number: 226). Note: gray= rock matrix; white=pyrite; blue $=$ irreducible water; red $=$ oil.

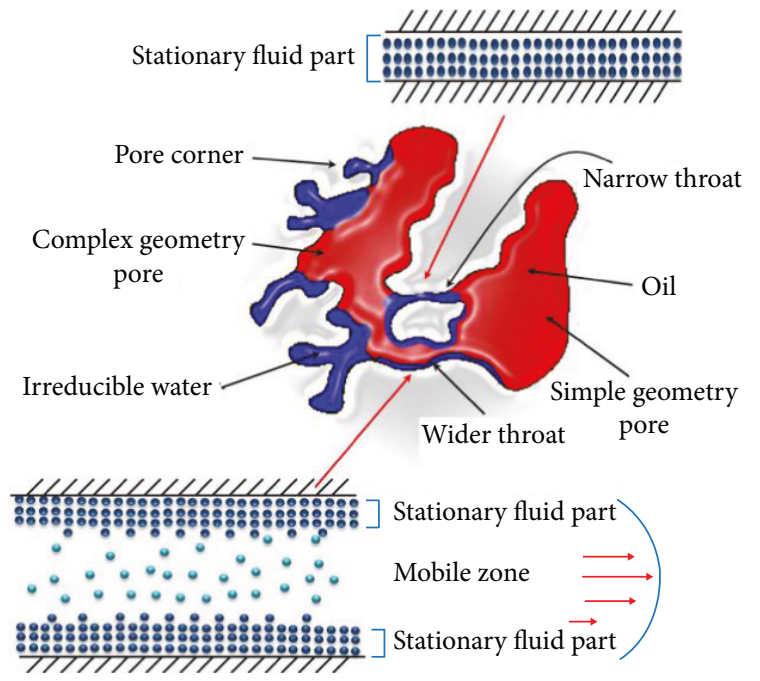

FiguRE 8: Schematic of irreducible water distribution in the porethroat system.

water presence, it occupied a small volume and its flow is governed by the bottle-necking structure at certain positions as shown in (Figure 16(a)).

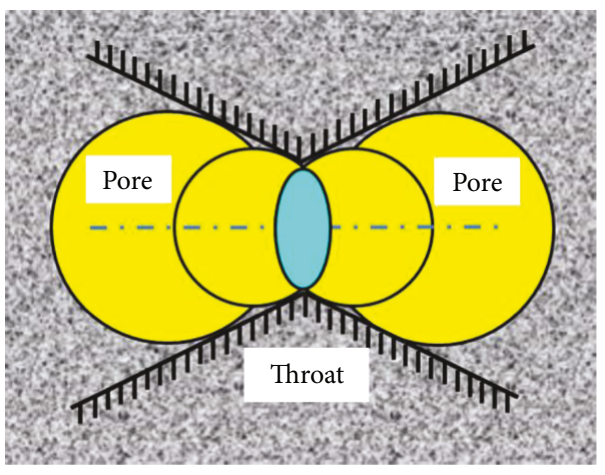

Figure 9: Pore and throat recognition principle.

(ii) Cluster shape: the cluster shape exists in a primary pore with the large compartment. However, due to surface roughness and complex pore geometry, the irreducible water present in the corner is linked to the adhered water film at other parts of the pore space (Figure 16(b)). This shape is more complicated than the water film but simpler than the conglobation shape.

(iii) Water film: this type of irreducible water appears as a water film which sticks to the 


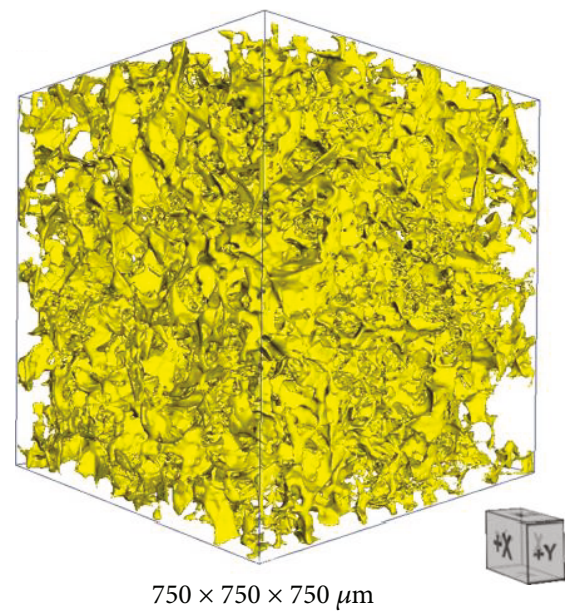

(a)

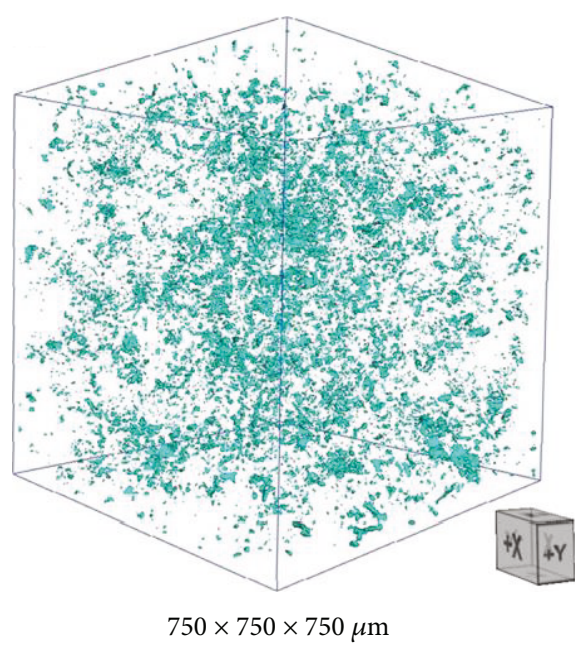

(b)

Figure 10: 3D structure: (a) pore system; (b) throat system. Note: length $\times$ width $\times$ height $=750 \times 750 \times 750 \mu \mathrm{m}$.

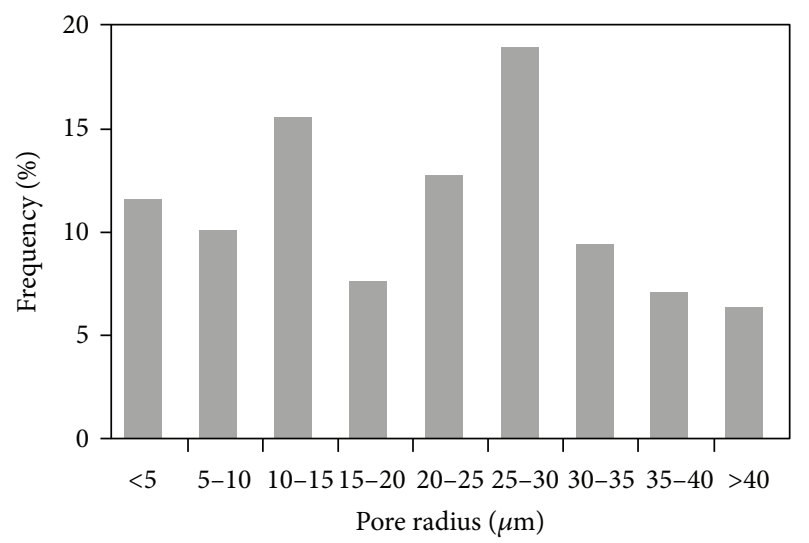

(a)

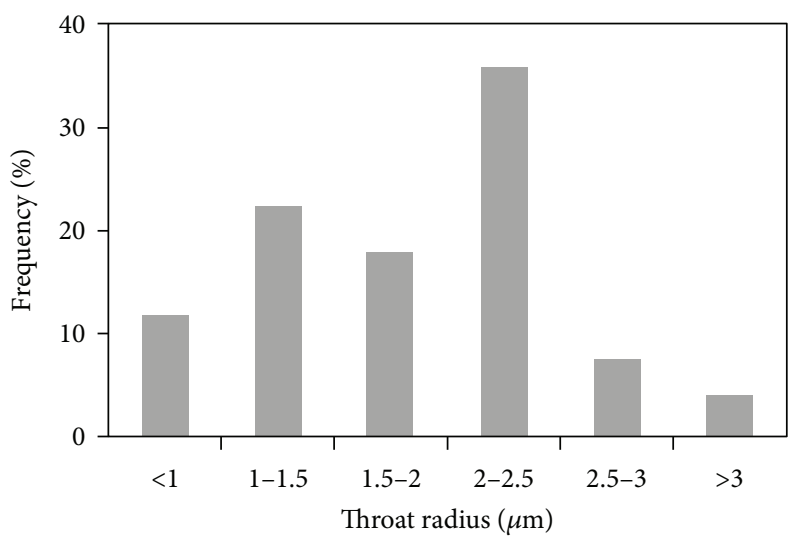

(b)

Figure 11: (a) Pore; (b) throat radius distribution of the core sample.

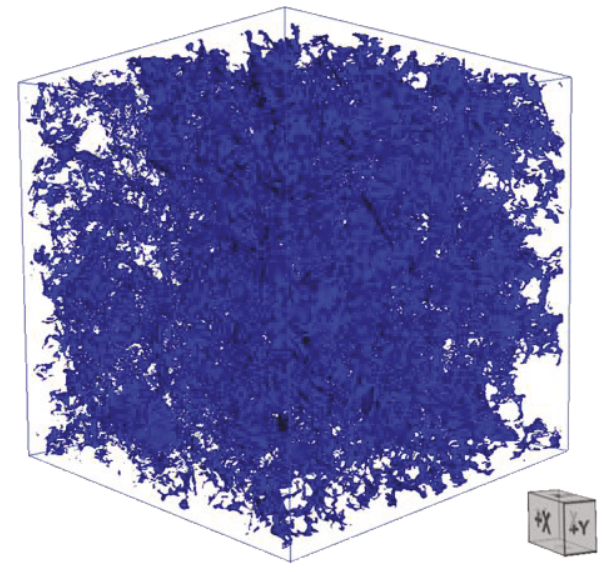

$750 \times 750 \times 750 \mu \mathrm{m}$

(a)

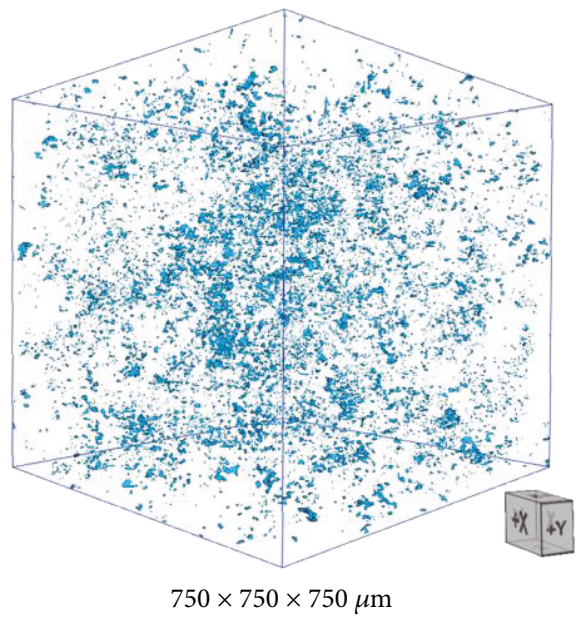

(b)

FIGURE 12: 3D distribution of irreducible water: (a) pore system; (b) throat system. 


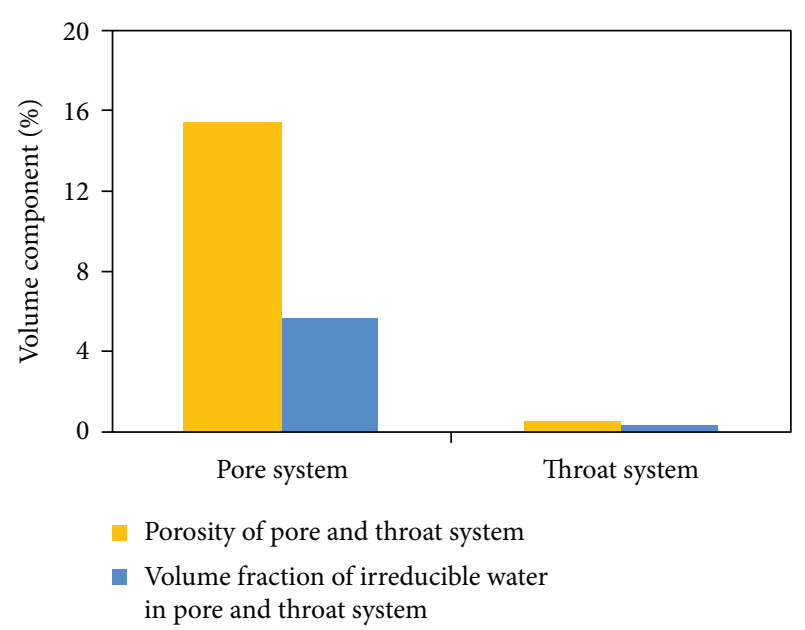

FIGURE 13: Histogram of irreducible water void space in the pore and throat system.

relatively smooth surface of regularly shaped pores (Figure 16(c)). However, it does not occupy all the rock surfaces.

(b) Irreducible water in the throat system:

(i) Curved piece-necking shape: this kind of throat structure featured with bottle-necking and curved segments besides microeffective seepage radius and large surface area. Consequently, it almost helps to fill the compartment entirely (Figure 17(a)).

(ii) Slug-filling shape: irreducible water locates precisely at the neck in the slug-filling shape. As a result, it blocks the path for the displacing oil. At the same time, it breaks the continuous oil phase which leads to high water drive pressure. However, upon entering into the wide segment of the same throat, the capillary force suddenly disappeared which tends to cease the spontaneous imbibition phenomenon (Figure 17(b)).

(iii) Water-film shape: we deal with that kind of irreducible shape, where it sticks to the surface throat in the form of a film, the so-called water film. Meanwhile, it reduced the effective radius for seepage. The channel radius and its complex geometry, the shape of irreducible water along with surface polarity of the pore-throat, are the controlling factors in the 3D distribution of irreducible water. Irreducible water sticks to the surface of the throat as the shape of the water film. Subsequently, the small seepage space is becoming much narrower (Figure 16(c)).

Figures 16(b), 16(c), and 17(c) show that the wetting phase (irreducible water) did not spread all over the surface. It is considered as the "mixed" wetting characteristics of the rock surface. Since the sandstone core sample is waterwetting in nature.But due to the presence of certain clay, for instance, chlorite, oil may wet certain parts of the entire surface. XRD of the core sample has been conducted which showed that chlorite content contributed around $17.5 \%$ of the core sample as shown in Table 2. In a nutshell, the oilwater interface in natural sandstone porous media is complex due to the influence of capillary trapping and the existence of oil-wetting clay. This phenomenon is in agreement with Trantham and Clampitt and Feng et al. [37, 38].

Irreducible water in the pore and throat system can be studied by $3 \mathrm{D}$ visualization technique. In this context, irreducible water distribution can be classified according to specific essential parameters, such as shape factors and irreducible water saturation. The standard classification is illustrated in Table 3.

Figure 18(a) shows the irreducible water frequency proportions in three kinds of irreducible water microoccurrence. In detail, the respective proportions in conglobation shape, cluster shape, and water film shape are $14.2 \%, 68.4 \%$, and $17.4 \%$, respectively. Figure 18(b) depicts the volume frequency of irreducible water microoccurrence in the throat system which is the curved piece-necking shape (16.9\%), slug-filling shape $(8.6 \%)$, and water-film shape (74.5\%). Therefore, the main irreducible water microoccurrence in pores and throats is in cluster and water-film shapes.

At the same time, from the results of the irreducible water microoccurrence, the water-film shape irreducible water is found to be unflowable in the pore-throat network. It is mainly attributed to the attractive force between the water film and the rock surface. As far as the other two kinds of irreducible water patterns, for instance, conglobation shape and cluster shape, are concerned, irreducible water should be confined by geological structure. It should be noted that these latter types of irreducible water could be fluidized using advanced technology, such as hydraulic fracturing.

Compared with irreducible water contained in the pore system, the microoccurrence of irreducible water in the throat system has severely influenced the oil-water twophase flow behavior. In the process of spontaneous imbibition, due to the capillary force, water is imbibed along narrow channels and crude oil is driven out from the pores through a comparatively larger size channel. As the saturation of irreducible water in the throat system is much higher than that in the pore system, the amount of imbibed water in the throat system will significantly be reduced. Additionally, some of the channels for crude oil are plugged due to the presence of irreducible slug water (curved piece-necking and slug-filling) in the throat system. Therefore, an inverse correlation between the saturation of irreducible water and spontaneous imbibition recovery could be concluded from this study. Last but not least, the role of lower rock permeability always linked with higher irreducible water saturation could also be explained in the above micromechanism.

\section{Conclusions}

(1) The micro geometric structures of the pore-throat systems have a significant influence on the microoccurrence of irreducible water in the low-permeability 


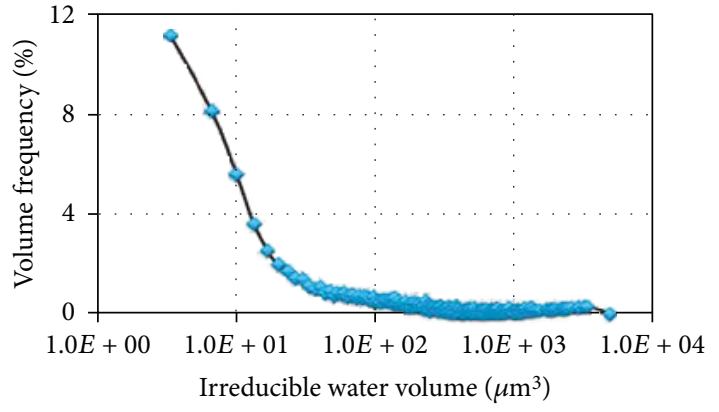

(a)

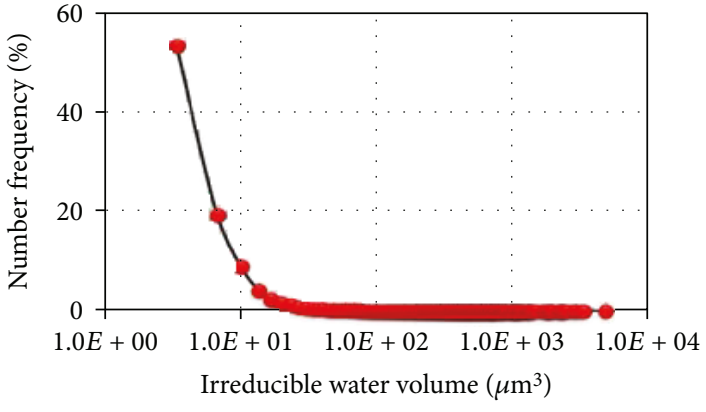

(b)

Figure 14: (a) Volume; (b) frequency number distribution of irreducible water blocks with different sizes in the throat system.

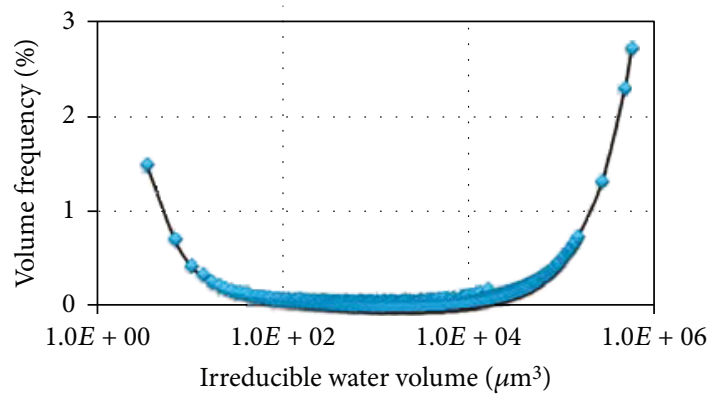

(a)

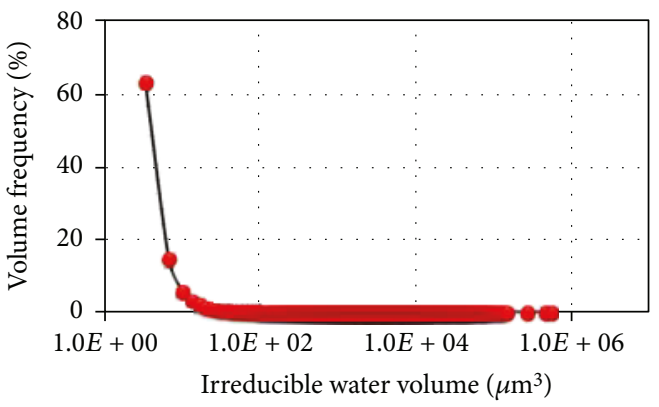

(b)

Figure 15: (a) Volume; (b) frequency number distribution of irreducible water blocks with different sizes in the pore system.

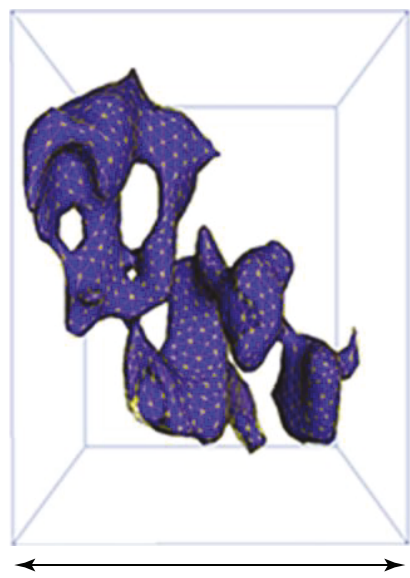

$50 \mu \mathrm{m}$

(a)

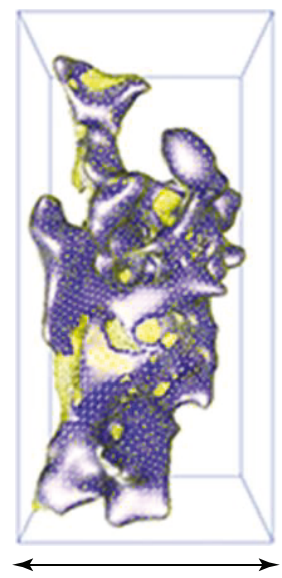

$70 \mu \mathrm{m}$

(b)

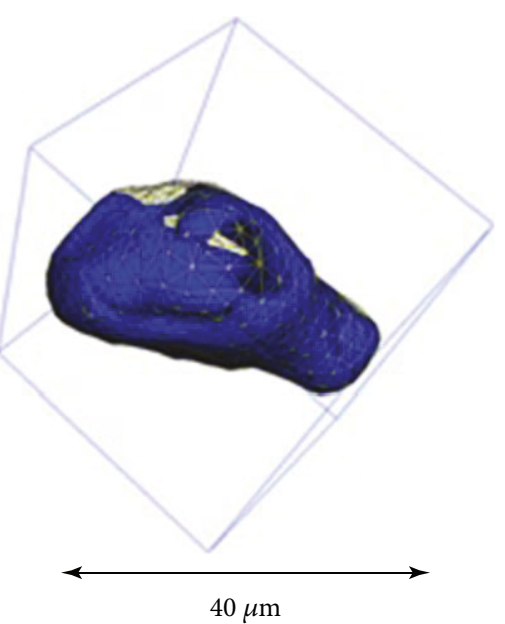

(c)

FIGURE 16: Different modes of irreducible water microoccurrence in the pore system: (a) conglobation pattern (ineffective oil reservoir space); (b) cluster pattern (partially effective oil reservoir space); (c) water-film pattern (effective oil reservoir space). Note: the yellow area represents a given pore or throat surface and the blue area represents irreducible water.

sandstone core sample. Certain core slices showed significantly different irreducible water saturation $(29.57 \%-50.69 \%)$ even though these slices had the same areal porosity.

(2) Due to the influence of capillary trapping and the existence of oil-wetting clay, the irreducible water saturation in the throat system (64\%) is much larger than that in the pore system (36\%). Furthermore, the wetting phase (irreducible water) did not spread all over the surface of the pore-throat network. Subsequently, oil-water two-phase interface becomes much more complicated.

(3) In the micro scale, the main irreducible water occurrence in the pore system is much different from that 


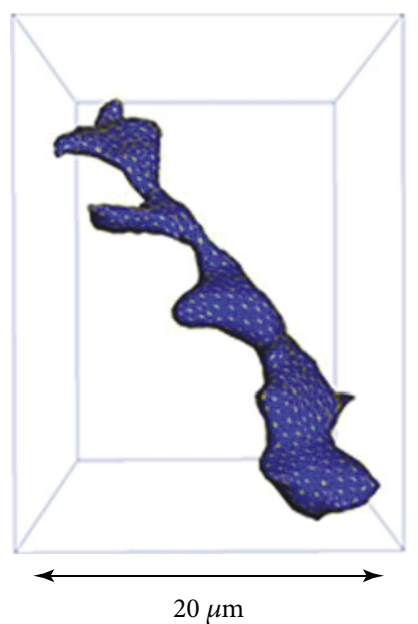

(a)

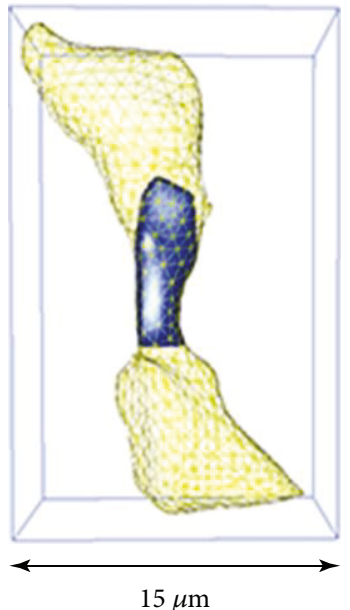

(b)

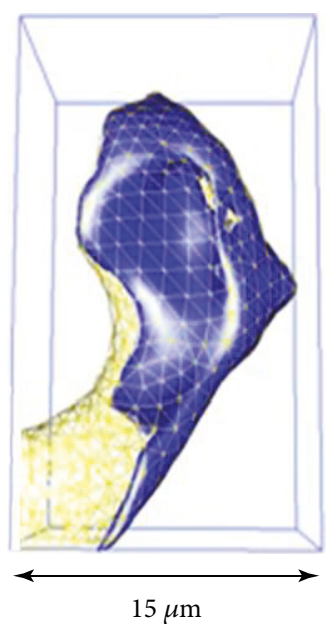

(c)

FIGURE 17: Different modes of irreducible water microoccurrence in the throat system: (a) curved piece-necking pattern (complete blockage, ineffective percolation channel); (b) slug-filling (partially blockage, ineffective percolation channel); (c) water-film pattern (partial blockage, effective percolation channel). Note: the yellow area represents a given pore or throat surface and the blue area represents irreducible water.

TABLE 2: XRD results of the core sample.

\begin{tabular}{lcccccc}
\hline Clay minerals & Quartz & Plagioclase & Potash feldspar & Calcite & Illite & Chlorite \\
\hline Wt. \% & 28.9 & 34.5 & 17.3 & 0.3 & 1.5 & 17.5 \\
\hline
\end{tabular}

TABLE 3: Classification of microcharacteristics of irreducible water in the pore and throat system.

\begin{tabular}{lccc}
\hline Unit & Irreducible water patterns & Shape factor ranges & Range of saturation of irreducible water in a single pore or throat \\
\hline \multirow{2}{*}{ Pore system } & Conglobation & $G<0.1$ & $90<S_{\text {Swi }}^{\prime}<100$ \\
& Cluster & $0.1<G<0.2$ & $30<S_{\text {Swi }}^{\prime}<90$ \\
& Water film & $0.2<G<0.4$ & $10<S_{\text {Swi }}^{\prime}<30$ \\
\hline \multirow{2}{*}{ Throat system } & Curved piece-necking & $G<0.2$ & $90<S_{\text {Swi }}^{\prime}<100$ \\
& Slug-filling & $0.4<G<0.7$ & $30<S_{\text {Swi }}^{\prime}<90$ \\
& Water film & $0.2<G<0.4$ & $10<S_{\text {Swi }}^{\prime}<30$ \\
\hline
\end{tabular}

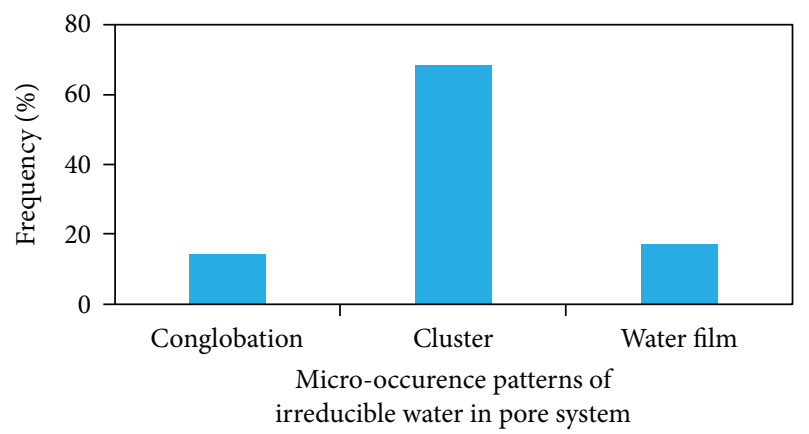

(a)

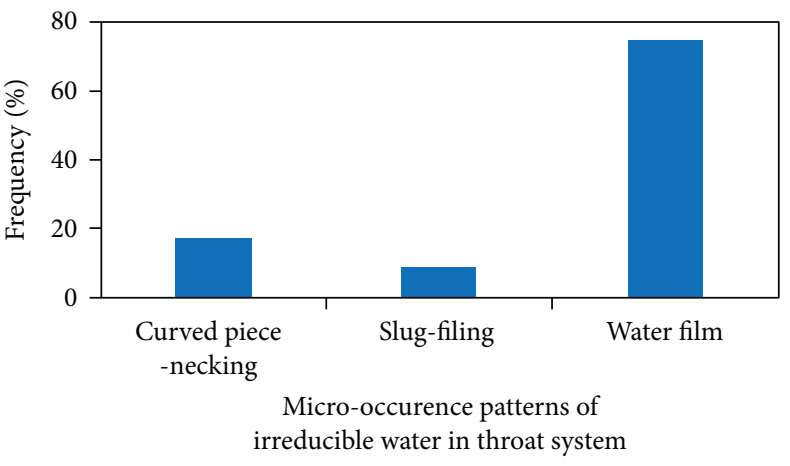

(b)

FIGURE 18: Histogram of irreducible water modes distribution: (a) pore system; (b) throat system. 
in the throat system. In the pore system, the irreducible water principally existed in the corner of the pores which are linked through the water film. While in the throat system, the irreducible water occurrence is dominated by the water film. However, 25.5\% of the throats are blocked by the irreducible water (curved piece-necking and slug-filling) which plug the crude oil drainage channels.

\section{Abbreviations}

CT: Computerized tomography

EOR: Enhance oil recovery

2D: Two dimensional

3D: Three dimensional

KI: $\quad$ Potassium iodide.

\section{Data Availability}

The data used to support the findings of this study are available from the corresponding author upon request.

\section{Conflicts of Interest}

The authors declare that they have no conflicts of interest.

\section{Acknowledgments}

The authors express their appreciation to the National Science and Technology Major Project (no. 2009ZX05009), the project of the China Natural Science Foundation (50774091) for the financial support of this work, and the China Postdoctoral Science Foundation (2018M631765): dynamic research on synergistic action of foam flooding stimulated by low-frequency vibration.

\section{Supplementary Materials}

Figure S1. XRD diffraction pattern of the experimental core sample. (Supplementary Materials)

\section{References}

[1] R. W. Bentley, "Global oil \& gas depletion: an overview," Energy Policy, vol. 30, no. 3, pp. 189-205, 2002.

[2] C. J. Campbell and J. H. Laherrère, "The end of cheap oil," Scientific American, vol. 278, no. 3, pp. 78-83, 1998.

[3] Z. Li, X. Qu, W. Liu, Q. Lei, H. Sun, and Y. He, "Development modes of Triassic Yanchang Formation Chang 7 Member tight oil in Ordos Basin, NW China," Petroleum Exploration and Development, vol. 42, no. 2, pp. 241-246, 2015.

[4] J. M. Dumore and R. S. Schols, "Drainage capillary-pressure functions and the influence of connate water," Society of Petroleum Engineers Journal, vol. 14, no. 5, pp. 437-444, 1974.

[5] J. T. Morgan and D. T. Gordon, "Influence of pore geometry on water-oil relative permeability," Journal of Petroleum Technology, vol. 22, no. 10, pp. 1199-1208, 1970.

[6] S. B. Coskun and N. C. Wardlaw, "Image analysis for estimating ultimate oil recovery efficiency by waterflooding for two sandstone reservoirs," Journal of Petroleum Science \& Engineering, vol. 15, no. 2-4, pp. 237-250, 1996.
[7] Y. Sun and D. City, "The influence of reservoir-forming dynamic on irreducible water saturation," Petroleum Geology \& Recovery Efficiency, vol. 13, no. 2, pp. 64-66, 2007.

[8] X. Gu, C. Pu, H. Huang et al., "Micro-influencing mechanism of permeability on spontaneous imbibition recovery for tight sandstone reservoirs," Petroleum Exploration and Development, vol. 44, no. 6, pp. 1003-1009, 2017.

[9] K. Li and R. N. Horne, "An analytical scaling method for spontaneous imbibition in gas/water/rock systems," SPE Journal, vol. 9, no. 3, pp. 322-329, 2004.

[10] J. Wang, Y. Liu, M. Chen, L. Liu, and J. Gao, "Experimental study on dynamic imbibition mechanism of low permeability reservoirs," Petroleum Exploration and Development, vol. 36, no. 1, pp. 86-90, 2009.

[11] N. K. Karadimitriou and S. M. Hassanizadeh, "A review of micromodels and their use in two-phase flow studies," Vadose Zone Journal, vol. 11, no. 3, pp. 215-228, 2012.

[12] I. Razmavar, F. M. Alami, M. R. Rasaei, and M. Nadafpour, "Microscopic fractal-dimension study of rate and viscosity changes on displacement pattern by use of $2 \mathrm{D}$ glass micromodel," SPE Reservoir Evaluation \& Engineering, vol. 20, no. 1, pp. 008-018, 2017.

[13] L. Haibo, G. Hekun, and L. Qiang, "NMR experimental study of water displacing oil of tight oil reservoir," Journal of Central South University: Science and Technology, vol. 45, no. 12, pp. 4370-4376, 2014.

[14] H. Doryani, M. R. Malayeri, and M. Riazi, "Visualization of asphaltene precipitation and deposition in a uniformly patterned glass micromodel," Fuel, vol. 182, pp. 613-622, 2016.

[15] L. Z. Huo, Z. Yang, and X. Liu, "Analysis of NMR moveable fluid parameters in ultra-low permeability glutenite reservoir," Science \& Technology Review, vol. 28, no. 7, pp. 88-90, 2010.

[16] H. Gao, Y. Liu, Z. Zhang, B. Niu, and H. Li, "Impact of secondary and tertiary floods on microscopic residual oil distribution in medium-to-high permeability cores with NMR technique," Energy \& Fuels, vol. 29, no. 8, pp. 4721-4729, 2015.

[17] P. Yang, H. Guo, and D. Yang, "Determination of residual oil distribution during waterflooding in tight oil formations with NMR relaxometry measurements," Energy \& Fuels, vol. 27, no. 10, pp. 5750-5756, 2013.

[18] T. R. Todoruk, C. H. Langford, and A. Kantzas, "Pore-scale redistribution of water during wetting of air-dried soils as studied by low-field NMR relaxometry," Environmental Science \& Technology, vol. 37, no. 12, pp. 2707-2713, 2003.

[19] Y. Li, H. Li, S. Chen, E. Mbia, K. Wang, and H. Ren, "Capillarity characters measurement and effects analysis in different permeability formations during waterflooding," Fuel, vol. 194, pp. 129-143, 2017.

[20] A. Polak, D. Elsworth, H. Yasuhara, A. S. Grader, and P. M. Halleck, "Permeability reduction of a natural fracture under net dissolution by hydrothermal fluids," Geophysical Research Letters, vol. 30, no. 20, 2003.

[21] M. Akbarabadi, S. Saraji, M. Piri, D. Georgi, and M. Delshad, "Nano-scale experimental investigation of in-situ wettability and spontaneous imbibition in ultra-tight reservoir rocks," Advances in Water Resources, vol. 107, pp. 160-179, 2017.

[22] L. E. Beckingham, C. A. Peters, W. Um, K. W. Jones, and W. B. Lindquist, "2D and 3D imaging resolution trade-offs in quantifying pore throats for prediction of permeability," Advances in Water Resources, vol. 62, no. 4, Part A, pp. 1-12, 2013. 
[23] Q. Luo, C. Zhang, Q. Dai et al., "Characterization of compact carbonate pore-throat network systems in the Xiagou Formation in Qingxi Sag, Jiuquan Basin, China," Journal of Petroleum Science \& Engineering, vol. 159, pp. 853-868, 2017.

[24] P. Iassonov, T. Gebrenegus, and M. Tuller, "Segmentation of $\mathrm{X}$-ray computed tomography images of porous materials: a crucial step for characterization and quantitative analysis of pore structures," Water Resources Research, vol. 45, no. 9, 2009.

[25] M. Wang, S.'a. Zhang, F. Zhang et al., "Quantitative research on tight oil microscopic state of Chang 7 Member of Triassic Yanchang Formation in Ordos Basin, NW China," Petroleum Exploration and Development, vol. 42, no. 6, pp. 827-832, 2015.

[26] P. Tiwari, M. Deo, C. L. Lin, and J. D. Miller, "Characterization of oil shale pore structure before and after pyrolysis by using X-ray micro CT," Fuel, vol. 107, no. 9, pp. 547-554, 2013.

[27] R. Song, M. Cui, J. Liu, P. G. Ranjith, and Y. Lei, “A pore-scale simulation on thermal-hydromechanical coupling mechanism of rock," Geofluids, vol. 2017, Article ID 7510527, 12 pages, 2017.

[28] F. F. Hingerl, F. Yang, R. Pini et al., "Characterization of heterogeneity in the Heletz sandstone from core to pore scale and quantification of its impact on multi-phase flow," International Journal of Greenhouse Gas Control, vol. 48, pp. 69-83, 2016.

[29] M. J. Blunt, M. D. Jackson, M. Piri, and P. H. Valvatne, "Detailed physics, predictive capabilities and macroscopic consequences for pore-network models of multiphase flow," Advances in Water Resources, vol. 25, no. 8-12, pp. 10691089, 2002.

[30] A. C. Gunde, B. Bera, and S. K. Mitra, "Investigation of water and $\mathrm{CO}_{2}$ (carbon dioxide) flooding using micro-CT (microcomputed tomography) images of Berea sandstone core using finite element simulations," Energy, vol. 35, no. 12, pp. 52095216, 2010.

[31] M. Zhou, D. Lu, J. Dunsmuir, and H. Thomann, "Irreducible water distribution in sandstone rock: two phase flow simulations in CT-based pore network," Physics and Chemistry of the Earth, Part A: Solid Earth and Geodesy, vol. 25, no. 2, pp. 169-174, 2000.

[32] X. Chen, Y. Liu, and Y. Wang, "Research on porosity of Chang 2 reservoir in Zichang oil field," Ground Water, vol. 23, no. 2, pp. 156-159, 2013.

[33] M. Andrew, Reservoir Condition Pore Scale Imaging of Multiphase Flow Using X-Ray Microtomography, Imperial Polytechnic University, 2014.

[34] H. Jian, Q. Maoxin, and L. Nu, "Characterization of residual oil microdistribution at pore scale using computerized tomography," Acta Petrolei Sinica, vol. 35, no. 2, pp. 319325, 2014

[35] D. Denney, "Robust determination of the pore-space morphology in sedimentary rocks," Journal of Petroleum Technology, vol. 56, no. 5, pp. 69-70, 2004.

[36] Z. Yang, X. F. Peng, D. J. Lee, and M. Y. Chen, “An imagebased method for obtaining pore-size distribution of porous media," Environmental Science \& Technology, vol. 43, no. 9, pp. 3248-3253, 2009.
[37] J. C. Trantham and R. L. Clampitt, "Determination of oil saturation after waterflooding in an oil-wet reservoir the North Burbank Unit, Tract 97 Project," Journal of Petroleum Technology, vol. 29, no. 5, pp. 491-500, 1977.

[38] C. Feng, Y. Shi, J. Hao et al., "Nuclear magnetic resonance features of low-permeability reservoirs with complex wettability," Petroleum Exploration and Development, vol. 44, no. 2, pp. 274-279, 2017. 

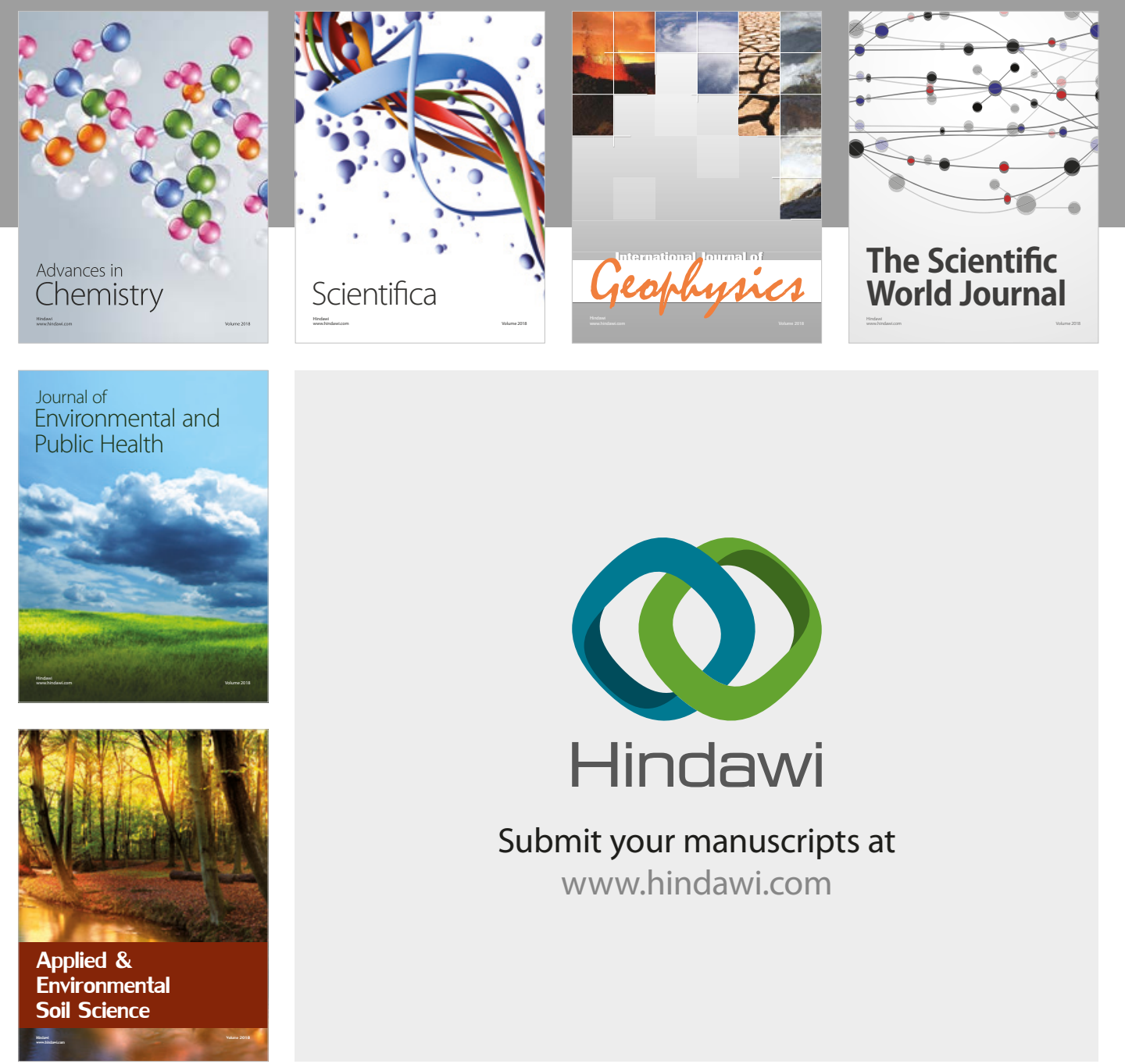

The Scientific

\section{World Journal}
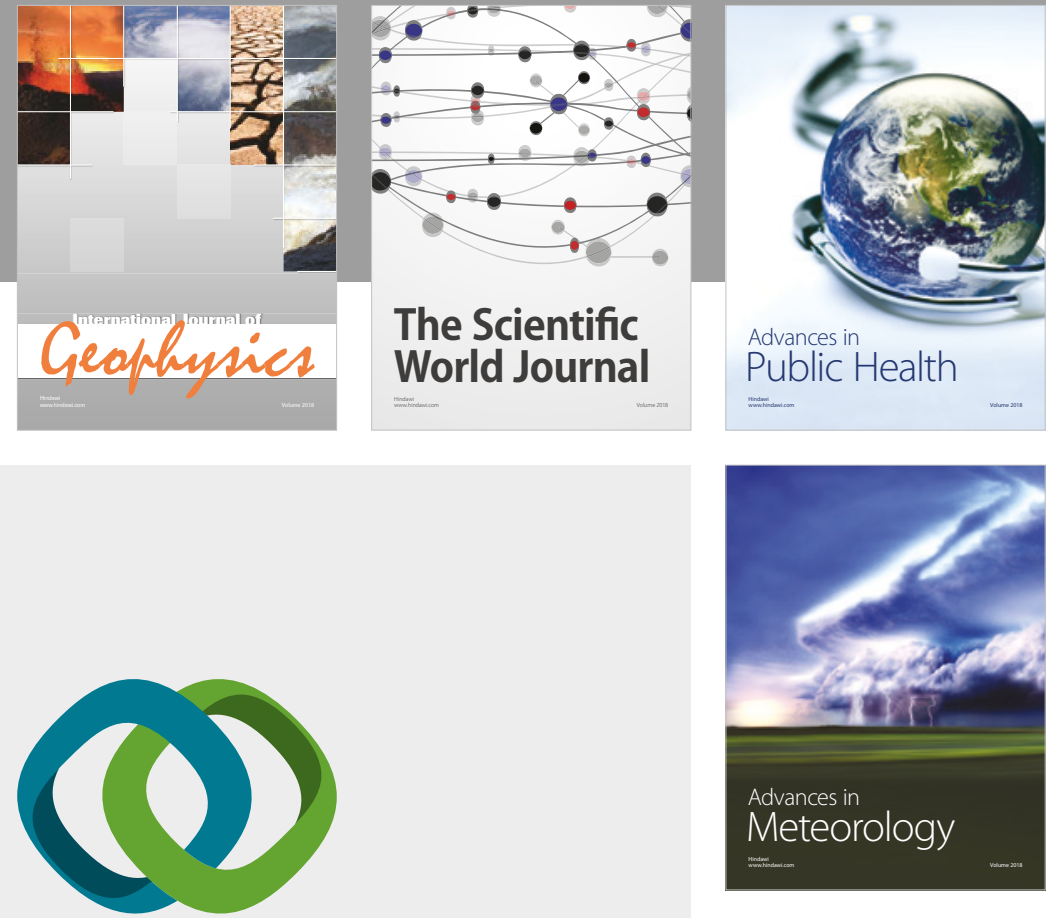

Advan

Public Health

\section{Hindawi}

Submit your manuscripts at

www.hindawi.com
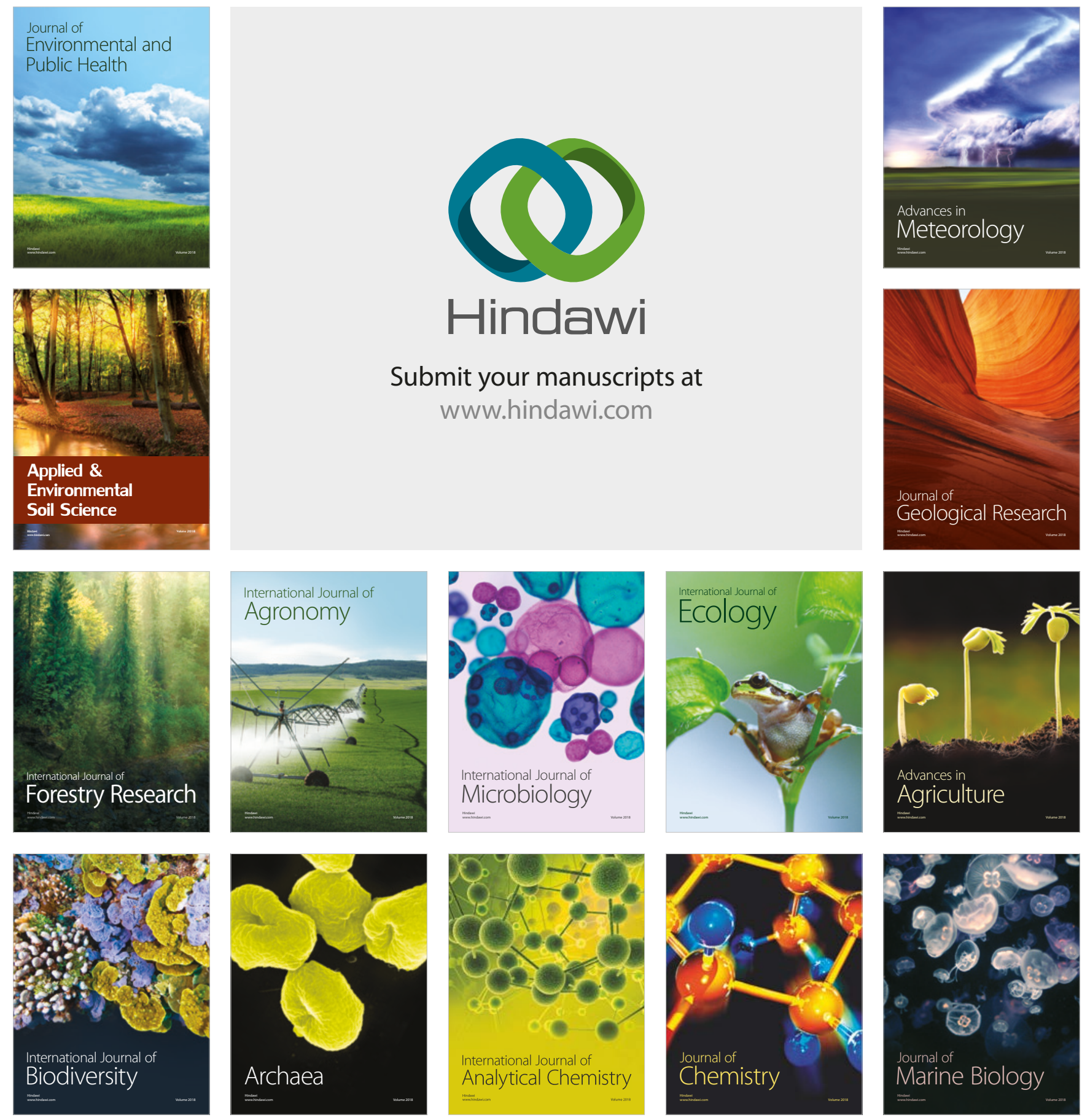